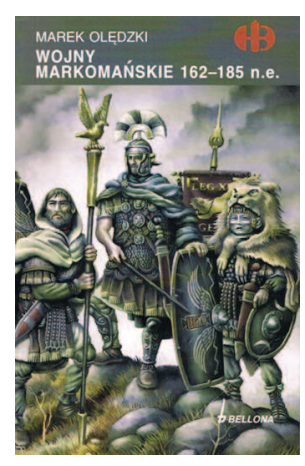

Mateusz Raszyński

(Poznań)

\section{O WOJNACH MARKOMAŃSKICH MARKA OLĘDZKIEGO}

DOI 10.14746/SEG.2014.9.16

Marek Olędzki, Wojny markomańskie $162-185$ n.e., Bellona, Warszawa 2011, 196 s., 25 ilustracji, dwie mapy

Wojny markomańskie, których znaczna część przypadła na panowanie cesarza Marka Aureliusza, bardzo długo przyciągały zainteresowanie badaczy. Od końca XIX wieku były one przedmiotem konferencji, dyskusji i sporów w zakresie społecznym, politycznym, kulturowym i gospodarczym. Ubogi materiał źródeł konwencjonalnych stale uzupełniano zabytkami epigraficznymi i numizmatycznymi. Dużą rolę odgrywały również odkrycia archeologiczne fortyfikacji obozowych z terenu limesu dunajskiego i reńskiego. Książka Marka Olędzkiego poświęcona tej tematyce wydawała się istotną dla polskiego czytelnika syntezą dotychczasowego stanu badań. Dodatkowo nawiązuje w pewnym stopniu do badań ujętych przez autora w pracy „Czas przemian: Barbaricum między Bałtykiem a środkowym Dunajem w dobie wojen markomańskich", wydanej w 2008 roku (jako praca habilitacyjna). Zawiera wstęp, w którym autor motywuje wybór tematu, następnie sześć rozdziałów oraz zakończenie. Pracę dodatkowo opatrzono dwudziestoma pięcioma ilustracjami, trzema aneksami, dwiema mapami oraz jedenastostronicową bibliografią. Wybór tematyki Olędzki motywuje konsekwencjami, które wojny markomańskie przyniosły historii Rzymu. Zaznacza poziom zniszczeń, porównując go do najazdu Cymbrów i Teutonów z końca II wieku p.n.e. Określa również ramy chronologiczne wojen, wychodząc poza przyjmowane dotąd w nauce lata 167-180.

Rozdział pierwszy („Rzym - między złotym wiekiem a wielkim kryzysem”, s. 9-24), wprowadza czytelnika w zagadnienia związane z przyczynami wybuchu wojen markomańskich. Z bibliografii wykorzystanej w tej części pracy jasno wynika, że książka skierowana została przede wszystkim do osób mających raczej ogólne bądź nawet mgliste pojęcie o historii starożytnej. Są to m.in. dość ogólna praca A. Ziółkowskiego „Historia Rzymu” (Poznań 2004) czy album „Rzym. Wielkie kultury świata" pod red. T. Cornella i J. Matthewsa (Warszawa 1995). Moją uwagę na temat potencjalnego odbiorcy potwierdza również dość obszerny opis funkcjonowania ustroju w Cesarstwie Rzymskim. Autor dużo miejsca poświęca sztuce rzymskiej z okresu Antoninów. Wśród dorobku literackiego epoki Olędzki 
wymienia przede wszystkim pisma medyka Galena, prace historyczne Appiana i Arriana, utwory Lukiana z Samosat, geograficzne dzieło Ptolemeusza, pisma apologetów (Tertulian, Klemens z Aleksandrii, Justyn z Nablusu). W pierwszym rozdziale Marek Olędzki w zarysie wymienia także czynniki, które jego zdaniem doprowadziły do zjawiska kryzysu w państwie rzymskim. Wskazuje tu przede wszystkim na tragiczne w skutkach rządy Kommodusa (którego częściowo rehabilituje w dalszej części pracy), czynniki ekonomiczne, takie jak psucie monety czy chociażby wzrost roli wojska w polityce, uwidoczniony przy obalaniu cesarzy Pertynaksa i Didiusa Juliana w 193 roku.

Rozdział drugi („Środkowoeuropejskie barbaricum - mozaika ludów i kultur”, s. 25-44) to rekapitulacja badań autora przedstawionych w wymienionej wyżej monografii. Autor, przy opisie geografii Germanii, dużo miejsca poświęca opisowi pozostałości archeologicznych odnajdywanych na tym terenie (przede wszystkim cmentarzyska, w tym tzw. królewski grób z Mušovy). Referuje także w zarysie dzieje „państwa” Markomanów w czasach Marboda oraz późniejsze losy plemienia i ich sąsiadów, bezpośrednio zaangażowanych w konflikt w latach sześćdziesiątych II wieku. Tutaj czytelnik znajduje także opis osadnictwa gockiego na ziemiach polskich, ale o celowości jego przedstawienia dowiaduje się dopiero w dalszej części pracy.

Trzeci rozdział („Uzbrojenie i sposoby walki głównych partnerów konfliktu”, s. 45-62), wydaje się również skierowany do czytelnika pozbawionego pogłębionej wiedzy o dziejach Cesarstwa Rzymskiego, zwłaszcza o jego wojskowości. $\mathrm{Na}$ uwagę zasługuje natomiast chociażby sztandarowa praca H.R. Robinsona „The Armour of Imperial Rome”. Olędzki wykorzystuje ciekawą, dobrą literaturę niemiecką poświęconą zagadnieniu rozmieszczenia wojsk rzymskich na limesie dunajskim, niepotrzebnie jednak zbyt obszernie wypowiada się na przykład na temat techniki budowania obozu rzymskiego. Rozdział został podzielony na trzy części: pierwsza poświęcona jest wojskowości rzymskiej, druga — barbarzyńskiej, trzecia natomiast stanowi próbę zestawienia potencjału obu zwalczających się sił.

W rozdziale czwartym („Przyczyny wiodące do wojen markomańskich”, s. 63-74) Marek Olędzki wychodzi z założenia, że przyczyny wojen markomańskich można podzielić na pośrednie i bezpośrednie. Jest to dosyć prosty, ale dopuszczalny schemat. Wśród czynników pośrednich wymienia m.in. zarazę, przyniesioną przez żołnierzy po wojnie na Wschodzie w pierwszej połowie lat sześćdziesiątych. Podkreśla wzrost siły ludów środkowoeuropejskich, przy okazji poświęcając sporo miejsca starożytnemu hutnictwu na ziemiach polskich, z naciskiem na rejon świętokrzyski. Warto wskazać, że M. Olędzki odchodzi od poglądu utrwalonego $\mathrm{w}$ polskiej historiografii przez Z. Haszczyca o słabym stanie wojsk rzymskich na limesie dunajskim w 166 roku. Autor podkreśla doświadczenie bojowe jednostek, 
które powróciły na granicę dunajską z frontu wschodniego, jak również umiejętną działalność dyplomatyczną komendantów granicznych garnizonów w okresie 162-166.

Piąty rozdział („Wojny markomańskie - przebieg konfliktu i jego trudno uchwytne zakończenie”, s. 75-124), najbardziej obszerny, stanowi zasadniczą część książki. Dzieli się na wstęp, sześć podrozdziałów oraz podsumowanie.

We wstępie znajdujemy krótką analizę źródeł, którymi dzisiaj dysponujemy dla odtworzenia chronologii konfliktu. Chodzi głównie o monety, inskrypcje oraz bogaty materiał archeologiczny, które uzupełniają tradycyjne dla historyka źródła pisane.

W pierwszym podrozdziale, „Bellum suspensum (lata 162-166)”, autor krótko nawiązuje do wojny z Partami na Wschodzie, wykazując bezpośredni związek konfliktu z najazdami plemion środkowoeuropejskich w tym okresie. Drugi podrozdział, „Okres intensywnych najazdów germańsko-sarmackich na Cesarstwo (lata 166/167-170)", poświęcony został pierwszemu etapowi zmagań. Autor wychodzi od wzmiankowanego przez Kasjusza Diona najazdu plemion znad dolnej Łaby, w dużej mierze Longobardów, do których dołączyli Obiowie. Olędzki datuje wydarzenie na zimę 166/167, podobnie jak inwazję Markomanów, Naristów i Kwadów. W dalszej części podrozdziału opisuje, w ogólnym zarysie, przebieg najazdów barbarzyńskich do 170 roku, z uwzględnieniem oblężenia Akwilei, datowanego na 169 rok.

Trzeci podrozdział, „Expeditio Germanica Prima” (lata 171-175)”, traktuje o stopniowej poprawie sytuacji Rzymian na froncie dunajskim i reńskim oraz przygotowaniach do ofensywy przeciwko Germanom i Sarmatom. Dokumentują to zwłaszcza emisje monetarne, opatrzone na rewersie legendą VIC(toria) GERM(anica). Początek ofensywy autor datuje na przełom 171/172 roku. Podrozdział kończy się wzmianką o uzurpacji Awidiusza Kasjusza i traktatach pokojowych zawartych z Kwadami, Markomanami i Jazygami.

Czwarty podrozdział opisuje działania wojenne w latach 177-180. Narracja autora na temat wojny $\mathrm{z}$ tego okresu uzależniona jest $\mathrm{w}$ dużej mierze od przekazu Kasjusza Diona, momentami dosłownie cytowanego (ale wyłącznie z wykorzystaniem przekładu angielskiego w edycji Loeb Classical Library). Krótki opis okupacji północnych brzegów Dunaju urozmaicony został bogatym sprawozdaniem na temat pozostałości po rzymskich fortach na tym terenie; autor największą uwagę skupił na stanowisku Stillfried w południowo-wschodniej Austrii, a także na obozach w Stupavie, Mušov, oraz trenczyńskim Laugaritio.

Piąty podrozdział poświęcony został rzadko poruszanej kwestii wojen na limesie już po śmierci Marka Aureliusza. Marek Olędzki skupia się na walkach z Burami 
w latach 182-183, wykorzystując tu m.in. pracę K. Dietza „Zum Ende der Markomannenkriege", który jako jeden z pierwszych badaczy wydłużył czas trwania wojen markomańskich. Wśród wykorzystanych źródeł pojawiają się tutaj inskrypcje, dotąd mało uwzględniane, oraz zniszczony papirus „oksfordzki”.

Ostatni podrozdział, zamykający opis wojen markomańskich, autor podsumowuje działalnością Sewerów na obszarze limesu dunajskiego, skupiając się zwłaszcza na czasach Karakalli. Uzasadnia to faktem, że najazd Kwadów i Jazygów w 212 roku na tereny Dacji, pierwszy od zakończenia wojny przez Kommodusa, i trwające potem działania zbrojne nad Dunajem (do roku 214) zamykają de facto cykl wydarzeń łączonych z wojnami markomańskimi. Przy okazji badacz dokonuje swoistej próby rewizji wizerunku „złego” cesarza Karakalli, utrwalonego w historiografii głównie za sprawą jego biografa w zbiorze Scriptores Historiae Augustae.

Rozdział szósty, „Rzymska polityka wobec ludów zza Dunaju — próba oceny”, to podsumowanie informacji na temat organizacji limesu na przestrzeni dwóch pierwszych stuleci Cesarstwa. Marek Olędzki nie zgadza się z teorią P. Kehne, zakładającą rozkład systemu państw klientelnych w okresie Marka Aureliusza. Autor „Wojen markomańskich” uważa, że w drugiej połowie II wieku n.e. stworzenie partnerskiej kooperacji z ludami środkoweuropejskiego barbaricum było niemożliwe ze względu na brutalny charakter wyzysku przez Rzymian ludów pogranicznych. W drugiej części rozdziału poświęca też trochę miejsca cesarzowi Markowi Aureliuszowi oraz jego następcy, Kommodusowi. Tego pierwszego przedstawia przede wszystkim przez pryzmat zachowanego tekstu jego autorstwa - „Rozmyślań”.

W pracy M. Olędzkiego pojawiają się niestety błędy edytorskie, tak jak np. przeinaczenie nazwiska „Mroziewicz” zamiast „Mrozewicz” w przypisie siódmym na stronie 11 albo nazwa plemienia „Kwaków” zamiast „Kwadów”. Olędzki zbyt często ucieka $\mathrm{w}$ narracji w stronę stylistyki literatury pięknej („W tej beczce miodu jest też łyżka dziegciu"). Ponadto prowadzi narrację w czasie teraźniejszym, zamiast przeszłym. W przypadku słowa stipendium, oznaczającego najczęściej zapłatę, żołd dla żołnierzy, stosuje błędną odmianę (błąd pojawił się trzy razy; „stipendiaea”, lub „stipendiae”). Niejasne są również przypisy, zwłaszcza przy cytowaniu źródeł. W przypadku „Germanii” Tacyta niepotrzebnie podaje stronę w wydaniu zamiast odpowiedniego rozdziału dzieła. Wykorzystuje również starsze (co nie oznacza, że gorsze) tłumaczenia. „Germania” doczekała się nowego wydania (Poznań 2008) w tłumaczeniu Tomasza Płóciennika, z gruntownym wstępem oraz komentarzem Jerzego Kolendo, ale Olędzki w bibliografii umieścił tylko wydanie z 1963 roku, w tłumaczeniu Seweryna Hammera. Bibliografia, choć bogata w trudno dostępne w Polsce prace niemieckojęzyczne, pozbawiona jest opracowań kluczowych, znanych nawet studentom (chociażby biografia Marka Aureliusza autorstwa Ch. Pa- 
raina, Marek Aureliusz, przeł. J. Rogoziński, Warszawa 1962; A. Birleya, Marcus Aurelius, New York 1987; P. Grimala, Marek Aureliusz, przeł. A. Łukaszkiewicz, Warszawa 1997). Pojawiają się często informacje, jak np. pojedynek rzymskiego wodza Marka Waleriusza Maksymianusa z wodzem Naristów Valao, bez odesłania do stosownego źródła. Zdarza się także nieprawidłowe cytowanie legend na monetach, np. VICTORIA GERMANICA, zamiast VIC(toria) GERM(anica); przy której przypis odsyła do starej pracy W. Zwikkera (Studien zur Markussäule, Amsterdam 1941) zamiast do katalogu monet.

Przy opisywaniu architektury monumentalnej cesarzy dynastii Antoninów autor odwołuje się jedynie do pracy Anny Sadurskiej „Archeologia starożytnego Rzymu" (Warszawa 1980), jakby lekceważąc nowsze opracowania. Wymienia bogaty dorobek literacki epoki Antoninów, zwracając uwagę na pisma Galena czy Lukiana, ale w dalszej części pracy rzadko stosuje odniesienia do wymienionych tekstów. Do czynników pogłębiających kryzys zalicza również „przeciążony budżet stałymi wydatkami na wojsko", ale trudno zgodzić się z tym twierdzeniem, ponieważ ze zjawiskiem „stałych wydatków na wojsko” mamy do czynienia już od momentu wprowadzenia regularnego żołdu oraz armii zawodowej blisko trzysta lat wcześniej przez Gajusza Mariusza, a w państwie Oktawiana Augusta wydatki na siły zbrojne sięgały $85 \%$ rocznego budżetu (ok. $480 \mathrm{mln}$ denarów). Zagadnienie związane $\mathrm{z}$ wojskowością rzymską, poruszone $\mathrm{w}$ drugim rozdziale pracy, to mimo wszystko powielenie dotychczasowych badań nad uzbrojeniem rzymskim, pozbawione jakichkolwiek przełomowych czy odkrywczych tez. Pewne niedociągnięcie można również dostrzec w opisie sceny z kolumny Marka Aureliusza, nazywanej „cudem pioruna” bądź „cudem burzy”. Autor jest przekonany, że jest to scena, w której doskonale widać wykorzystywanie machin oblężniczych przez barbarzyńców, podczas gdy zwykły czytelnik (a do takiego właśnie kierowana jest książka) nie jest w stanie dostrzec nic poza zarysem postaci (scena jest bardzo zniszczona). Na podstawie kolejnego reliefu z kolumny Marka Aureliusza Marek Olędzki forsuje tezę, że w drugiej połowie II wieku wśród rzymskich legionistów dominował pancerz folgowy, lorica segmentata. Jednak na scenach z kolumny Marka Aureliusza widzimy żołnierzy rzymskich, w tym również legionistów, ubranych głównie w zbroje kolcze, czyli lamelkowe. Pisząc o kataklizmie ze 166 roku, autor odwołuje się zaledwie do krótkiego ustępu z biografii Marka Aureliusza w SHA, podczas gdy poświadczają go również współcześni wypadkom Galen i Lukian, piszący zaledwie pięćdziesiąt lat później Kasjusz Dion czy też w IV wieku Eutropiusz. W tym wypadku SHA powinno się chronologicznie wymienić na samym końcu.

Autor w czwartym rozdziale podkreśla rolę świętokrzyskiego ośrodka hutniczego $\mathrm{w}$ procesie rozwoju środkowoeuropejskiego barbaricum, ale poświęca mu 
zdecydowanie za dużo miejsca, uciekając w niepotrzebną dygresję, zwłaszcza że już ponad dwadzieścia lat temu stosowną pracę napisała J. Drążyk („Wyroby pochodzenia rzymskiego w północno-wschodnim rejonie gór świętokrzyskich”, Antiquitas XV, 1992, s. 5-21), do której wystarczyłoby wykonać tylko przypis. Praca J. Drążyk nie znalazła się jednak nawet w bibliografii Marka Olędzkiego. Nieco przesadnie $\mathrm{w}$ rozdziale piątym autor określa działalność dyplomatyczną rzymskich namiestników wobec agresywnych plemion, którzy jakoby „nadludzkim wysiłkiem powstrzymywali konflikt”. Już od czasów Augusta pieniądze były znaną techniką wstrzymującą napór barbarzyńców na granice Imperium, co podkreślił Tacyt w „Germanii” (42). W przypadku określenia bellum suspensum autor odsyła czytelnika do niewłaściwego miejsca w biografii Marka Aureliusza w SHA: nie 13.1, lecz 12.13. Jest to efekt korzystania wyłącznie z przekładu, a nie z edycji tekstu oryginalnego.

Kontrowersyjny wydaje się również opis kwestii utworzenia dwóch nowych legionów przez Marka Aureliusza (legio II i III Italica). M. Olędzki wskazuje, że sam pomysł był wynikiem najazdu barbarzyńców, podczas gdy zarówno starsza literatura (C.H. Dodd, Chronology of the Danubian Wars of the Emperor Marcus Antoninus, Numismatic Chronicle XIII, 1913, s. 162-199; A. Birley, The Invasion of Italy in the Reign of Marcus Aurelius, [w:] Provincialia. Festschrift R. Laur-Belart, Basel 1968, s. 214-225), jak i nowsza (chociażby P. Kovacs, Marcus Aurelius' Rain Miracle and the Marcomannic Wars, Boston 2009) przypisują misję tworzenia nowych legionów Markowi Frontonowi. Miał ją otrzymać po powrocie ze Wschodu w 166 roku. Ich utworzenie nie było konsekwencją zarazy, jak upatruje M. Olędzki we fragmencie SHA, lecz wiązało się z projektem utworzenia nowych rzymskich prowincji na północ od Dunaju.

W tekście brak jest odniesienia do opuszczenia przez Rzymian kopalń złota w Dacji, co dosyć dokładnie datuje się na maj 167 roku. Autor odwołuje się także do fragmentu dzieła Ammiana Marcelina, ale błędnie je interpretuje, ponieważ pisarzowi z IV wieku wcale nie chodziło o unaocznienie łupieżczych i haniebnych działań barbarzyńców, ale pochwałę cnót społeczeństwa rzymskiego.

Niewiele miejsca poświęcono opisowi konkretnych działań związanych z rzymską kontrofensywą ze 172 roku, ograniczając się zaledwie do pojedynczych fragmentów dzieła Kasjusza Diona, który również nie pozostawił nam obszernej relacji (M. Olędzki natomiast nazywa epitomę dzieła Kasjusza Diona „dokładnym opisem"). Brakuje analizy składu osobowego najbliższego otoczenia Cesarza, którego dokonał już A. Mócsy w pracy na temat Panonii (Pannonia and Upper Moesia: a History of the Middle Danube Provinces of the Roman Empire, przeł. na j. ang. S. Frere, London 1974), czy A. Birley w biografii Marka Aureliusza (1987). Autor 
uważa, za Z. Haszczycem $(1976,1977)$, że plany utworzenia nowych prowincji zadunajskich, Markomanii i Sarmacji, narodziły się dopiero w efekcie zwycięstw odniesionych w starciu z Germanami i Sarmatami. Zdaniem jednak P. Kovacsa plany te powstały już w roku 166, a może nawet w 165, w ramach koncepcji dokonania uderzenia wyprzedzającego.

Przy próbie stworzenia wizerunku cesarza Marka Aureliusza w ostatnim rozdziale autor niepotrzebnie cytuje całe fragmenty „Rozmyślań”, bez jakiegokolwiek komentarza. Trudno też jest zgodzić się z jego opisem Kommodusa. Mówienie, że był on w społeczeństwie znienawidzony dlatego, że prezentował się jako wcielenie Herkulesa, jest dużym uproszczeniem. Musiałoby to bowiem dotyczyć także cesarza Trajana, który również nawiązywał do mitu o herosie. Niechęć do ostatniego Antonina wynikała raczej ze złego doboru cech, eksponowanych przez Kommodusa, który widział w Herkulesie uosobienie nadludzkich sił i niestrudzonego wojownika (stąd przedstawienia w skórze lwa i z maczugą w prawej ręce).

Praca Marka Olędzkiego o wojnach markomańskich to mimo wszystko ważna pozycja na polskim rynku wydawniczym. Książka ukazuje konflikt nie tylko z perspektywy źródeł pisanych (głównie Kasjusz Dion i SHA), ale także, a może przede wszystkim, przez pryzmat danych archeologicznych. 